International Journal of Social Sciences and Humanities
Available online at http://sciencescholar.us/journal/index.php/ijssh
Vol. 2 No. 2, August 2018, pages: $65 \sim 76$
e-ISSN: 2550-7001, p-ISSN: 2550-701X
http://dx.doi.org/10.29332/ijssh.v2n2.128

\title{
Influence of Human Capital, Social Capital, Economic Capital towards Financial Performance \& Corporate Social Responsibility
}

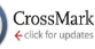

\begin{abstract}
Ni Nyoman Juli Nuryani a , Dewa Putu Rida Satrawan ${ }^{\text {b }}$, Anak Agung Ngurah Oka Suryadinatha Gorda ${ }^{\text {, }}$ Luh Kadek Budi Martini ${ }^{\mathrm{d}}$
\end{abstract} \\ Article history: Received 9 August 2017, Accepted in revised form 1 March 2018, Approved 28 May 2018, \\ Available online 1 June 2018
}

Correspondence Author a

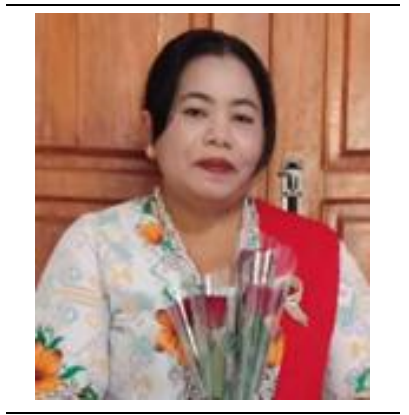

Keywords

Social capital;

Human capital;

Economic capital;

Financial performance;

Corporate social

responsibility;

\begin{abstract}
The study was intended to determine the influence of human capital, social capital, and economic capital on LPD financial performance in Buleleng regency as well as their influence of financial performance on corporate social. The sampling technique was used purposive sampling, primary data collection (questionnaire) and secondary data (LPD financial report) 50 respondents. Data analysis method in the present research was a descriptive statistic and inferential statistic analysis. Data processing techniques were used in Smart PLS applications. Based on the research result was obtained human capital construct relationship value $(1,858)<t$ table $(1,96)$, with a coefficient value of 0,193 means that the relationship was positive but not significant. Social capital construct relationship (2.667)> t table (1.96) with a coefficient value of 0.194 means that the relationship was positive and significant. The economic capital construct relationship of $(5,853)>t$ table $(1,96)$ with a path coefficient of $-0,697$ means the relation was negative and significant. The construction of financial performance relation of $(3,797)>t$ table $(1,96)$ with a path coefficient of 0,669 means that the relationship was positive and significant. Regarding its determination coefficient of financial performance, construction was explored by the construct of human capital, social capital, the economic capital was $80 \%$, whereas, the construct of corporate social responsibility was elaborated by the construct of financial performance was $44.80 \%$ and the rest was influenced other variables not listed in this research.
\end{abstract}

e-ISSN : 2550-7001, p-ISSN : 2550-701X ๑ Copyright 2018. The Author. SS Journals Published by Universidad Técnica de Manabí. This is an open-access article under the CC BY-SA 4.0 license (https://creativecommons.org/licenses/by-sa/4.0/) All rights reserved.

\footnotetext{
a STIE Satya Dharma, Singaraja, Indonesia

b STIE Satya Dharma, Singaraja, Indonesia

c University of National Education, Indonesia

d Mahasaraswati University, Denpasar, Indonesia
} 


\section{Contents}

Abstract

1. Introduction

Literature Review

66

2. Research Methods

68

3. Results and Analysis

70

3.1 Result

70

3.2 Analysis

71

4. Conclusion 72

Conflict of interest statement and funding sources.

Statement of authorship

Acknowledgements.

References.

Biography of Authors.

\section{Introduction}

Capital is an important factor in order to build, develop, and maintain company establishment. It was used as an instrument to anticipate company's loss risk and tools to expand the business. The company currently is faced with the development of technology (technology-driven business). Human resources (HR) involved in every activity, the company will do less physical work and do using brain capital, it is known as intellectual capital (Pablos, 2000).

HR or human capital is a very important and strategic capital in a company's life. The investments made for HR improvement are not small, however, the results are hard to feel in the short term. In addition, human capital is company core. One of the capitals inherent in human is social capital.

Social capital is very important in the formation of human capital. It is often used as a filter to pass through the flow of human resources and financial capital from the society, resulting in better education levels. If social capital is low, it will lead to a conflict of values and low trust. It means the importance of increasing participation in social relations in transitional countries or regions to produce HR to achieve better development.

The above capitals have an important role in improving the company financial performance, however, the loss risk also needs to be considered. Economic capital is in the spotlight due to the influence performance measurement capabilities, risk-sensitive approaches and optimal capitalization of the calculation functions, especially, in the banking industry or financial institutions, risk management activities and adequate capital level calculation have been a very popular issue for decades (Tiryaki 2009). The third role of capital above aims to always improve the company financial performance. Financial performance is used as a measure of the company condition to determine the company is in good or bad condition. It is to show that the financial performance is needed to know and evaluate the company success level based on financial activities that have been implemented. If the company has made a maximum profit through the capital, they have. It is currently required to pay attention to the stakeholder's role, therefore, it should be able to align the company with them by developing corporate social responsibility programs.

In Bali, Lembaga Perkreditan Desa (LPD) is a very popular financial institution in the society. LPD is the provision of financial services for the social nature, from society and for society. LPD is also formed as a part or unit of traditional villages in Bali that serves to store funds, channel credit, and loans to the society in accordance with the provisions and the regional regulations I Bali. For LPD, the financial performance is one of the most important factors in the healthy business development and can minimize the loss risk. If LPD's financial performance is good, it is expected to increase LPD growth for the long term, on the contrary, if poor LPD financial performance will decrease LPD growth. Thus, it is a case with giving CSR to the society. In accordance with Governor Regulation (PERGUB), No. 11 in 2013 Section 75 paragraph 1 stipulates the distribution of net profit of LPD at the end of accounting year shall be determined included (1) village development fund 20\%; (2) social fund 5\%. Therefore, the CSR amount of LPD to the public is determined by the profit at the end of the year.

Regarding the LPD development is quite rapidly in Bali. It is proved the eight LPDs in 1984 then in 2016, the number has reached 1.443 LPDs. Those are spread across nine regencies/cities in Bali. Specifically, there 
are twenty-seven LPDs in Buleleng regency that are unhealthy and jammed. Some of them are unhealthy and even stalled due to the lack of management of their human capital and public trust (social capital). It will be surely a special scourge for LPD considering the LPD role existence helps the economic growth of the society in desa pakraman. Therefore, it is necessary to conduct a study on the financial performance assessed from human capital, social capital, economic capital in order to increase social contribution to the society in the CSR form. Based on the background exposure that has been presented above, the problem can be formulated as follows:

1) What the human capital influence the LPD financial performance in Buleleng Regency?

2) What the social capital influence the LPD financial performance in Buleleng Regency?

3) What the economic capital influence the LPD financial performance in Buleleng Regency?

4) What the financial performance influence the Corporate Social Responsibility (CSR) of LPD in Buleleng Regency?

\section{Literature Review \\ Human Capital}

Human is as the main stakeholder in the organization. Wherein, the human ability in one company is different to another. Therefore, due to the performance achievement of each company will have a different experience. According to Tobing (2007) explained that the human capital notion in accordance with the Skandia Value Scheme, that human capital included all the individual capacities, talents, knowledge, and experiences of workers and managers as well as the competencies, capabilities, relationships, and values of employees. Becker (2000) proposed the theory of human capital as quoted by Maymand et.al. (2015) defined the human capital as an investment for organizations in terms of education and training for employees aimed at enhancing employee knowledge, skills, and competency and ultimately contributes to maximizing organizational productivity and output. It can be explained that Human Capital is the company's intangible assets in the form of ability, intelligence, talent, creativity, innovation, and experience owned by employees to support the long-term sustainability of the company and contribute to maximizing productivity.

\section{Social Capital}

Social capital is the institution's social relations, values, and interaction attitudes among employees who have contributed to the economic and social development in the company. Coleman (1988) defined that social capital as a variety of different entities, with two elements in common: they all consist of some aspect of social structure, and they facilitate certain actions of actors - whether personal or corporate actors - within the structure. Putnam (1993), viewed that social capital as a set of horizontal associations between people. Social capital contains social networks (networks of civic engagement) and norms that influence the social productivity. Social capital is an asset that is determined by social associations both internally and externally. It becomes a resource that reflects the goals and mutual trust between existing employees, then creates value that will facilitate the collective action (Molina, 2010). The above description of social capital can be defined as social capital is an asset determined by social associations both internally and externally which bind members in a network. According to Ridell (in Suharto, 2005), social capital indicator, there are three social capital parameters included trust, norms, and networks.

\section{Economic Capital}

The concept behind the economic capital model is a return on a transaction or business needs to be assessed by comparing it to their risks arising from a particular transaction or business. Economic capital is evaluated as a buffer towards unexpected future losses at a certain confidence level. Bank managers can be better equipped to estimate potential problems with advanced and established economic capital models (Burns, 2005). Economic capital is the amount of capital set aside by the bank as a buffer towards potential losses from its business activities. It is used to protect bondholders and depositors (Cap Gemini, 2010). It can be stated that economic capital is the amount of money capital needed to identify the risks or potential losses associated with transactions, business units or whole companies.

Financial Performance

Nuryani, N., Satrawan, D., Gorda, A., \& Martini, L. (2018). Influence of human capital, social capital, economic capital towards financial performance \& corporate social responsibility. International Journal of Social Sciences And Humanities (IJSSH), 2(2), 65-76. doi:10.29332/ijssh.v2n2.128 
The company as one of organization form generally have a specific goal to be achieved in an effort to meet the interests of its members. The success in achieving company goals is a management achievement. The performance assessment or performance of a company is measured. Due to it can be used as a basis for decision making both internal and external parties. Fahmi (2012) stated that financial performance is an analysis conducted to know how far the company has implemented by using the rules of financial implementation properly and correctly. Rudianto (2013) stated that the financial performance is the results or achievements that have been achieved by the company's management in carrying out its functions effectively manage the assets of the company for a certain period. It can be concluded that financial performance is a formal business that has been conducted by companies that can measure the success of the company in generating profit. Therefore, in order to see the prospects, growth, and potential development of both companies by relying on existing resources. A company can be stated to succeed if it has reached the predetermined standards and objectives.

Corporate Social Responsibility (CSR)

The term CSR was first published in the social responsibility of the businessman in 1953. The concept was initiated by Howard Rothmann Browen (1953) addresses the concerns of the business world. It is stated that the existence of CSR is not due to it is mandatory by the government or the ruler, but rather a commitment that is born in the context of business ethics (beyond legal aspects) to prosper with the society based on the principles of propriety according to the values and the society needs. CSR as action form that was started from the ethical considerations of the company directed to improve the economy coupled with the improvement of the life quality for employees and their families, as well as improving the life quality for the surrounding society and to be a better society (Hadi 2014). CSR definition is also similar to Tarmizi expression (in Oktafianti and Rizki, 2015). CSR reporting is the process of conveying the social and environmental impacts of economic actions undertaken by corporations on particular groups in the overall society. It can be concluded that CSR is an organization's social responsibility to the impact of its activities on society and the environment embodied in the form of transparent and ethical behavior in accordance with the sustainable development and welfare of surrounding societies.

\section{Research Methods}

Theoretical Framework

The companies must be aware of the existence of increasingly fierce and free competition requires the company must prepare as possible, including related to the management of each company's assets. Capital is an important factor in order to build, develop, and maintain the company establishment. According Mayo (2000) measured that the company performance from their financial perspective is very accurate but actually the basis of driving the financial value is human capital. In addition, human capital is the company core. One of the capitals inherent in human is social capital often is used as a filter that must be passed where the flow of HR and financial capital of the society. The result is in better education both capital above has an important role in improving financial performance a company, but the loss risk also needs to be considered. In measuring the loss risk, economic capital is considered most appropriate for the possible risks prevention.

The assessment of the company performance can be conducted by analyzing the financial statements. It is the end result of the accounting activities of the company concerned. The number of company profits earned can measure the company's influences in generating profits by utilizing assets owned by the company. In order to cope the consequences of the company's activities, the company performs its social responsibility to its environment, or what is often called Corporate Social Responsibility (CSR). Based on the previous description mentioned, the related variables in the present study can be formulated through a theoretical framework as follows: 


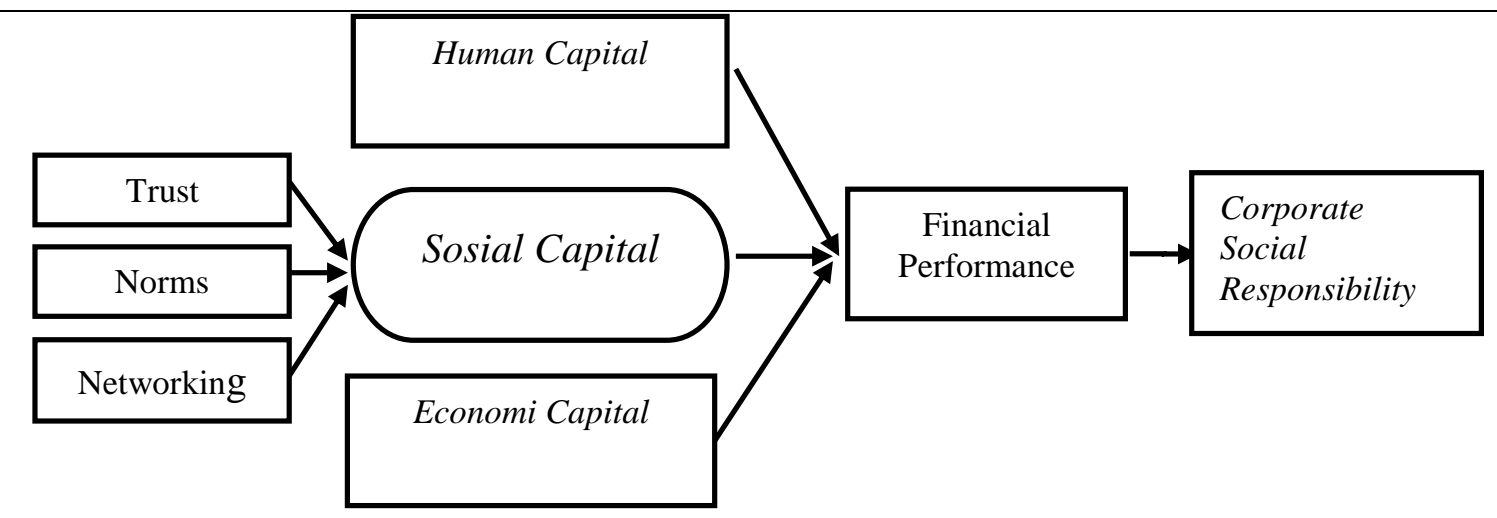

Figure 1. The framework of human capital, social capital, economic capital, financial performance \& corporate social responsibility

\section{Research Location}

Research location is a research object. The location was selected LPD that are ranked 1 to 50 based on asset ownership in Buleleng Regency. It is in the healthy category and has complete financial reporting in 2016.

\section{Population and Sample}

The total number of LPDs in Buleleng Regency is 169, consisting of 119 healthy LPDs, 10 healthy LPDs, 10 unhealthy LPDs, 3 unhealthy LPDs, and 27 loss LPDs. The 119 healthy LPDs, there are 19 LPDs that not have complete financial statements. Therefore, LPD is healthy and has a complete financial report is $101 \mathrm{LPD}$. Thus, the population in this study is 100. From the above population and sample, there is a healthy LPD and has complete financial statements. The sample used is 50 LPD in Buleleng Regency.

\section{Data Type}

The data types are required to carry out research on LPDs in Buleleng Regency as follows:

a) Quantitative data i.e., financial statement data and asset data as well as the health condition of LPDs Buleleng Regency per the year 2016.

b) Qualitative data i.e., data in the form of descriptions or references of the company profile in general, the LPD companies location in Buleleng Regency.

\section{Data Source}

Based on the source, the research data can be grouped into two types included primary and secondary data. Primary data in this research is the answer result of LPD leader (respondent) in filling questioner for SC variable. Secondary data in this research is financial report data and asset data as well as the health condition of LPD in Buleleng Regency per the year 2016 and LPD profile in general.

\section{Data Collection Techniques}

Data collection technique used in this study included documentation techniques i.e., LPD financial statements that become the object of this study. The questionnaire is the respondent's answer (LPD leader) on the question posed for the SC variable.

\section{Data Processing Technique and Data Analysis}

The data analysis method in this study is divided into two i.e., descriptive statistics and inferential statistical analysis included evaluation of measurement model and structural model.

Nuryani, N., Satrawan, D., Gorda, A., \& Martini, L. (2018). Influence of human capital, social capital, economic capital towards financial performance \& corporate social responsibility. International Journal of Social Sciences And Humanities (IJSSH), 2(2), 65-76. doi:10.29332/ijssh.v2n2.128 


\section{Results and Analysis}

\subsection{Result}

Data processing technique is used SEM method based on Partial Least Square (PLS). SEM PLS analysis consists of two submodels namely measurement model or outer model and structural model or often called inner model. Regarding the high index value of each indicator, it can be summarized that LPD receives enormous trust from the society in terms of products utilization offered by LPD. This is due to LPD is a village financial institution that is managed for the progress of the village itself. It is bound by the awig-awig already agreed by the society itself.

Based on the social capital table descriptive is known that social capital management in LPD. It is at the level of 1 to 50 have social capital very good. It can be seen from index value. It is very high that is 40,50 . The evaluation of measurement model can be seen at significance value of Weight T-Statistics. If the value is $>1.96$ and P-value $<0.05$ then it can be concluded that the construct indicator is appropriate as a constructor gauge. In this research, it can be seen that T-statistics value of all social capital constructs indicators as the table below:

Tabel 1

Outher weight

\begin{tabular}{lccccc}
\hline & $\begin{array}{c}\text { Original } \\
\text { Sample (0) }\end{array}$ & $\begin{array}{c}\text { Sample } \\
\text { Mean (M) }\end{array}$ & $\begin{array}{c}\text { Standard } \\
\text { Deviation (STDEV) }\end{array}$ & $\begin{array}{c}\text { T Statistics } \\
(\mid \text { O/STDEV|) }\end{array}$ & P Values \\
\hline CSR <- CSR & 1.000 & 1.000 & 0.000 & & \\
EC <- Economic_Capital & 1.000 & 1.000 & 0.000 & & \\
HC <- Human_Capital & 1.000 & 1.000 & 0.000 & & \\
FP <- Financial_Performance & 1.000 & 1.000 & 0.000 & & \\
SC1 -> Social_Capital & 0.827 & 0.714 & 0.358 & 2.310 & 0.021 \\
SC2 -> Social_Capital & 1.081 & 1.088 & 0.339 & 3.193 & 0.001 \\
SC3 -> Social_Capital & -1.639 & -1.509 & 0.372 & 4.411 & 0.000 \\
\hline
\end{tabular}

Source: data processed

Table 1 of outher weight above can be seen that the T-statistics value of SC variable construct indicator has value $>1,96$ and its P-value $<0,05$. It can be stated that all constructs indicator is appropriate as SC construct gauge.

In assessing the model with PLS begins at looking R-square for each dependent latent variable. Table 2 is the result of R-square estimation using SmartPLS can be seen table R-square as the table below:

Table 2

R-square value

\begin{tabular}{lll}
\hline \multicolumn{2}{c}{ R Square } \\
\hline CSR & 0,4480 \\
FP & 0,8000 \\
\hline
\end{tabular}

Source: data processed

Table 2 above the determination coefficient of CSR is 0.4480 . It means that CSR variables can be explained by the financial performance of $44.80 \%$. The value of FP is 0.8000 . It has meaning FP variables can be explained by human capital, social capital, and economic capital of $80 \%$ and the remaining $20 \%$ is influenced by other variables that exist in this research. 
Tabel 3

Path Coefficients

\begin{tabular}{lccccc}
\hline & $\begin{array}{c}\text { Original } \\
\text { Sample (0) }\end{array}$ & $\begin{array}{c}\text { Sample } \\
\text { Mean (M) }\end{array}$ & $\begin{array}{c}\text { Standard } \\
\text { Deviation (STDEV) }\end{array}$ & $\begin{array}{c}\text { T Statistics } \\
(\mid \text { O /STDEV|) }\end{array}$ & P Values \\
\hline EC - FP & -0.697 & -0.729 & 0.119 & 5.853 & 0.000 \\
HC -> FP & 0.193 & 0.163 & 0.104 & 1.858 & 0.063 \\
KK -> CSR & 0.669 & 0.668 & 0.176 & 3.797 & 0.000 \\
SC -> FP & 0.194 & 0.190 & 0.073 & 2.667 & 0.008 \\
\hline
\end{tabular}

Source: data processed

Observing the results in the above table, the first hypothesis shows that the relationship of the human capital variable to financial performance shows the value of the path coefficient is 0.193 with t-value is 1.858 . The value is smaller than t-table of 1.96. It means hypothesis 1 is rejected. The second hypothesis shows that the relationship of the social capital variable to financial performance has a coefficient value of 0.194 and $t$ value of 2.667. The value of $t$ is higher than t-table is 1.96. It means hypothesis 2 accepted. The third hypothesis shows that the relationship of the economic capital variable to financial performance has a coefficient value of -0.697 and $\mathrm{t}$-value of 5.854 . The $t$ value of the economic capital variable is higher than the value of $\mathrm{t}$-table. It means hypothesis 3 is accepted. The fourth hypothesis shows that the correlation of variable of financial performance with corporate social responsibility has lane coefficient value is 0,669 with t-value is 3,797 higher than t-table is 1,96 . It means hypothesis 4 accepted.

\subsection{Analysis}

Based on the research results that has been described previously, the following will be discussed analysis related to the research results that has been conducted and answer the problem formulation.

a) Relationship of human capital and financial performance

The influence of human capital on financial performance of LPD has a T-statistic value of 1.858. Looking at t-statistic $>\mathrm{t}$ table $(1.858<1,96)$, the influence of human capital on LPD financial performance is positive but not significant with the coefficient value of 0.193 (original sample value). The value means that human capital is not able to improve the financial performance of LPD. It is seen in the T-statistic value of $1.858<1.96$. The value significance is the utilization of human capital in LPD has not been maximized and has not been used as LPD asset. Therefore, human capital in LPD is only used as a burden of LPD revenue reduction. Therefore, it is important to do how LPD to manage the human resources to support the best performance. The best performance is important for LPD to increase profits that will ultimately impact CSR to the stockholders, in this case the society of desa pakraman.

b) Relationship of social capital and financial performance

The influence of social capital in LPD financial performance, has T-statistic value of 2.6668. Looking at the $t$-statistic $>t$ table $(2,667>1,96)$, the influence of social capital on financial performance of LPD is positively significant with the path coefficient value of 0.194 (original sample value). Based on this result, the social capital measured by trust, norms and networks has a significant influence on the improvement of LPD financial performance in Buleleng regency. It indicates that the higher value of social capital in LPD, the higher value of LPD financial performance in Buleleng regency.

Social capital as measured by trust, norms and networks is closely related to the improvement of financial performance as measured by the profit generated by LPD. The public trust has an important role for LPD to improve financial performance, when people have strongly believed that the existence of LPD, the excess funds owned by the society will be invested into LPD itself, in the form of savings and time deposits. Similarly, the norms (awig-awig), regarding awig-awig who remembers and/or regulates LPD operations, therefore, the public increasingly believes in saving funds or loan a credit in LPD. Regarding the business networks that are woven with various parties in terms of UN payments services, water payments from PDAM and electricity from PLN. It also causes the society will always do

Nuryani, N., Satrawan, D., Gorda, A., \& Martini, L. (2018). Influence of human capital, social capital, economic capital towards financial performance \& corporate social responsibility. International Journal of Social Sciences And Humanities (IJSSH), 2(2), 65-76. doi:10.29332/ijssh.v2n2.128 
transactions in LPD. Thus, the ability of LPD in generating profits not only obtained from savings and lending activities only.

c) Relationship of economic capital and financial performance

The influence of economic capital on financial performance of LPD has a T-Statistic value is 5.853. The provision of $t$-statistics $>$ from $t$-table $(5,853>1,96)$, the influence of economic capital on LPD financial performance in Buleleng regency is negatively significant with coefficient value is -0.697 . Based on the above results can be stated the relationship of economic capital and financial performance in LPD Buleleng regency has a negative and significant relationship. The economic capital measured by the unsettled receivables account is considered capable of explaining performance improvement. LPD finance in Buleleng regency as measured by the amount of profit generated. This study can explain that the management of the capital amount used in anticipation of losses suffered by LPD is lower in number or LPD is able to minimize the amount reserves receivables hesitate to anticipate the losses risk due to loan given. The higher ability of LPD in generating profits due to capital is used in loss es anticipation due to bad loan slightly. In other words, the lower economic capital value is the better LPD financial performance of Buleleng regency.

d) Relationship of LPD financial performance and corporate social responsibility

The influence of LPD financial performance on corporate social responsibility has value of 3.797 . The provision of t-statistics $>$ of t-table $(3.797>1.96)$. Thus, the influence of financial performance on CSR provision is positively significant with the value of the coefficient path is 0.669 . This research is able to explain that regarding improvement of LPD financial performance measured from profit has a positive and significant correlation to CSR LPR improvement. It means that the higher value of LPD financial performance is the higher CSR that will be given by LPD.

CSR program is one of the obligations that must be implemented by LPD in accordance with Bali Provincial Regulation No.8, in 2002 on LPD. CSR provided to the society is basically can not be felt quickly, but will have a big impact on the future, the greater provision of CSR to the society indicates that the better profit generated by LPD itself. The provision of CSR is $25 \%$ net income obtained by LPD. CSR provided will definitely give reciprocity from the society. It is the level of confidence that is increasing as well, with the public trust to LPD, hence the interest to confidence their fund fixed to LPD.

\section{Conclusion}

The results provide answers and conclusions on the problems formulation presented. There are four conclusions that can be described as follows:

1) Human capital constructs have a positive influence but not significant on LPD financial performance. In the outer weights table, the value of P-value is $>0.05$, that is 0,063 and the T-statistic value is 1,858 $<1,96$ ( $\mathrm{H} 1$ accepted). It can be stated that showing the results of P-values and T-statistic that HC constructs can not explain financial performance. This is due to LPD has not maximally utilized human capital as an asset owned by LPD itself.

2) Social capital construct has a positive influence and significant on LPD financial performance in Buleleng regency. In the outer weights table, $\mathrm{P}$-value is $<0.05$, it can be stated that all construct indicators are appropriate as social capital construct gauges. Furthermore, T-statistic value is $2.667 .>\mathrm{t}$ table of 1.96 (H2 accepted). The value states that the higher social capital construct value, the higher LPD financial performance.

3) Economic capital construct has a negative influence and significant on LPD financial performance. This can be seen from P-value is $<0,05$ that is 0.000 and T-statistic value $>1,96$ that is equal to 5,858 (H3 accepted). If it is seen from the value of original sample economic capital construct has value -.0697 . Based on the value can be concluded that the smaller economic capital value, the higher LPD financial performance value. It can also be stated that the smaller the reserves of doubtful accounts in the LPD, the higher LPD financial performance is better.

4) Financial performance construct has a positive influence and significant on CSR (Social Corporate Responsibility). This can be seen from the T-statistics value of 3.797 is higher than t-table of 1.96 (H4 accepted). This value means that the higher financial performance value, the higher CSR value is given by LPD. 
Conflict of interest statement and funding sources

The authors declared that they have no competing interest. The study was financed by personal funding.

\section{Statement of authorship}

The authors have a responsibility for the conception and design of the study. The authors have approved the final article.

\section{Acknowledgments}

The authors thank the editors of IJSSH for their valuable time and advice. 


\section{References}

1. Adetunji, A. T., Adetunji, A. V., Adeleke, E. O., \& Madubuike, S. C. (2017). Deregulation: The Effect of Marketled Approach to Nigerian Universities Management. International Journal of Social Sciences and Humanities (IJSSH), 1(1), 1-8.

View in (Google Scholar)

2. Basel Committe on Banking Supervision. (2009). Consultative Document, Overview of The New Basel Capital Accord.

View in (Google)

3. Becker, G. (1964). Human capital national bureau of economic research. New York, 11.

View in (Google Scholar)

4. Burns, R. L. (2004). Economic capital and the assessment of capital adequacy. Supervisory Insights, 2(2), 511.

View in (Google Scholar)

5. Coleman, J. S. (2000). Social capital in the creation of human capital. In Knowledge and social capital (pp. 17-41).

View in (Google Scholar)

6. Dewi, I. G. A. A. O., \& Dewi, I. G. A. A. P. (2017). Corporate Social Responsibility, Green Banking, and Going Concern on Banking Company in Indonesia Stock Exchange. International Journal of Social Sciences and Humanities (IJSSH), 1(3), 118-134.

View in (Google Scholar)

7. Fahmi, I. (2012). Analisis kinerja keuangan. Bandung: Alfabeta.

View in (Google Scholar)

8. Mayo, A. (2000). The role of employee development in the growth of intellectual capital. Personnel Review, 29(4), 521-533.

View in (Google Scholar)

9. McWilliams, A., \& Siegel, D. (2000). Corporate social responsibility and financial performance: correlation or misspecification?. Strategic management journal, 21(5), 603-609.

View in (Google Scholar)

10. Molina-Morales, F. X., \& Martínez-Fernández, M. T. (2010). Social networks: effects of social capital on firm innovation. Journal of Small Business Management, 48(2), 258-279.

View in (Google Scholar)

11. Oktafianti, D. (2015). Pengaruh Kepemilikan Manajerial, Ukuran Perusahaan dan Kinerja Keuangan Terhadap Corporate Environmental Disclosure Sebagai Bentuk Tanggung Jawab Sosial dalam Laporan Tahunan (Studi pada Perusahaan Peserta Proper 2011-2013) (Doctoral dissertation, Universitas Airlangga). View in (Google Scholar)

12. Peraturan Gubernur Bali. Nomor 11 Tahun 2013. Tentang Petunjuk Pelaksanaan Peraturan Daerah Provinsi Bali Nomor 8 Tahun 2002 Tentang Lembaga Perkreditan Desa Sebagaimana Telah Diubah Beberapa Kali Terakhir Dengan Peraturan Daerah Provinsi Bali Nomor 4 Tahun 2012 Tentang Perubahan Kedua Atas Peraturan Daerah Provinsi Bali Nomor 8 Tahun 2002 Tentang Lembaga Perkreditan Desa, Bali. View in (PDF) 
13. Putnam, R. D., Leonardi, R., \& Nanetti, R. Y. (1993). Making democracy work: Civic institutions in modern Italy.

View in (Google Scholar)

14. Rudianto. (2013). Akuntansi Manajemen Informasi untuk Pengambilan Keputusan Strategis. Jakarta: Erlangga.

View in (Article)

15. Suardana, I. B. R., Astawa, I. N. D., \& Martini, L. K. B. (2018). Influential Factors towards Return On Assets and Profit Change. International Journal of Social Sciences and Humanities (IJSSH), 2(1), 105-116.

View in (Google Scholar)

16. Suharto, E. (2007). Modal sosial dan kebijakan publik. tersedia di http://www. policy. hu/suharto/Naskah\% 2OPDF/MODAL_SOSIAL_DAN_KEBIJAKAN_SOSIA. pdf, diakses tanggal, 28.

View in (Google Scholar)

17. Tiryaki, G. (2011). Basel regulations, economic capital and their implications for the Turkish banking industry. Doğuş Üniversitesi Dergisi, 10(1), 118-133.

View in (Google Scholar)

18. Tobing, P. L. (2007). Knowledge management: konsep, arsitektur dan implementasi. Yogyakarta: Graha Ilmu.

View in (Google Scholar)

Nuryani, N., Satrawan, D., Gorda, A., \& Martini, L. (2018). Influence of human capital, social capital, economic capital towards financial performance \& corporate social responsibility. International Journal Of Social Sciences And Humanities (IJSSH), 2(2), 65-76. doi:10.29332/ijssh.v2n2.128 


\section{Biography of Authors}

\begin{tabular}{|c|c|}
\hline & $\begin{array}{l}\text { Ni Nyoman Juli Nuryani was born in Sangkaragung on July 6, 1976. She is } \\
\text { currently a lecturer in the College of Economics (STIE) Satya Dharma Singaraja. } \\
\text { She graduated her bachelor degree in Mahasaraswati University, Denpasar. She } \\
\text { finished her Master degree in Gajayana University, Malang and she completed her } \\
\text { P.hD. in Udayana University. She as well as the Chairman of STIE Satya Dharma } \\
\text { Singaraja. } \\
\text { Email: nijuli.nuryani07@gmail.com }\end{array}$ \\
\hline & $\begin{array}{l}\text { Dewa Putu Rida Sastrawan was born in Banyupoh on March 23, 1992. He } \\
\text { graduated his Diploma level and Bachelor degree in STIE Satya Dharma Singaraja. } \\
\text { His profession as an entrepreneur and as a research assistant. } \\
\text { Email: detoerida69@gmail.com }\end{array}$ \\
\hline & $\begin{array}{l}\text { Anak Agung Ngurah Oka Suryadinatha Gorda was born in Denpasar on March 22, } \\
\text { 1970. He is a lecturer in National Education University (Undiknas Denpasar). He } \\
\text { graduated his bachelor degree in the Faculty of Economics, Undiknas Denpasar. He } \\
\text { finished his Master degree in the Institute of Bogor Agriculture (IPB). He } \\
\text { completed his P.hD. in Airlangga University (Uniar), Surabaya. He as well as a } \\
\text { researcher that is interested in economics and social sciences. } \\
\text { Email: okagorda@gmail.com }\end{array}$ \\
\hline ageas dast & $\begin{array}{l}\text { Dr. Luh Kadek Budi Martini, SE., MM., was born in Kusamba Klungkung on March } \\
\text { 22, 1975. She graduated her bachelor degree in the Faculty of Economics, } \\
\text { Undiknas Denpasar in 1987. She finished her Master degree at Magister of } \\
\text { Management Program (MM), Airlangga University in 2000. She completed her } \\
\text { P.hD. degree at Udayana University in 2017. Since 2005, she is a lecturer in the } \\
\text { Faculty of Economics, Mahasaraswati University (Unmas) Denpasar. She is as well } \\
\text { as diligent to conduct on management research, individually and groups. She is an } \\
\text { ethic \& personality development instructor/trainer, communication skills and } \\
\text { service excellent, and public speaking skills. } \\
\text { Email: jrseruni@gmail.com }\end{array}$ \\
\hline
\end{tabular}

